Bull. Fac. Agric., CairoUniv., 71:121-128(2020).

\title{
PRELIMINARY STUDY ON GERMINABLE WINTER WEED SEED BANK AT GIZA FARM RESEARCH STATION, AGRICULTURAL RESEARCH CENTER, EGYPT
}

(Received: 8.7.2020)

\author{
By \\ Maha F. El-Enany, Enas M. Kamel and S. D. M.Eid \\ Weed Research Central Laboratory, Agricultural Research Center, Giza, Egypt.
}

\begin{abstract}
Recently, weed seed bank studies became a milestone and a crucial component of weed management in agro-ecosystems in the world. Uptill now, there are a few studies about weed seed bank in Egypt. For this reason, establishing weed seed bank studies isneeded for weed management in Egypt.The present study was carried out during 2018 and 2019 winter seasons toevaluatethe magnitude of the non-dormant weed seed bank of winter annual weeds in five different basins at Giza Research Station.Weed seed germination was kept under observation for a period of six weeks andthe germinated seeds were counted weekly and removed after that.The results indicated that most of weed seeds were concentrated in the above $0-5 \mathrm{~cm}$ layer followed by $5-10 \mathrm{~cm}$ layer, and the lowest ones were found in $10-15 \mathrm{~cm}$ layerfrom soil surface.Most of weed seeds were germinated in the $1^{\text {st }}$ and $2^{\text {nd }}$ weeks, and decreased gradually in the next weeks, where about $95 \%$ of weed seeds in soil profile were germinated in the first five weeks. The existed weed flora contained 18 species which differedin their densities from one basin to another.The highest number of germinated weed seeds were recorded in basin 20 (375.5 and 456.88 seedlings $/ \mathrm{kg}$ of soil) in $1^{\text {st }}$ and $2^{\text {nd }}$ seasons, respectively, while the east number of germinated weed seeds was found in basins 19 and 6 (65.56 and 87.69 seedlings/ $/ \mathrm{kg}$ of soil) in $1^{\text {st }}$ and $2^{\text {nd }}$ seasons, respectively. By using ANOVA statistical analysis experimental error decreased by taking 3-4 soil samples, to give adequate accuracy for soil seed bank determination than taking one soil sample.In conclusion weed seed bank determination in soil is a key for sustainable agriculture in Egypt. The present study throws the light on vertical or horizontal distributions in soil profile in seed bank as a good tool for improving weed management in cropping system in Egypt.
\end{abstract}

Keywords: seed bank, CV\%(Coefficient variance), experimental error, soil depth.

\section{INTRODUCTION}

Weeds have always been a problem in cropping systems. High weed densities reduce crop yield and quality. Understanding weed seedbank dynamics will improve the efficiency of weed managementby understanding how long seeds remain viable in the seedbank and how those seeds are related to the aboveground weed community. A producer could tailor weed management programs to increase efficiency. Khan et al. (2012) found thatthemajority of weed seeds germinated in the soil samples collected from the above $5 \mathrm{~cm}$ of the soil surface. However, most of the weed seeds germinated in the first two weeks of the experiment.

Sampling field soils for determining seed bank are confined to the surface and upper 30 $\mathrm{cm}$ of soil. The horizontal distribution of seeds across soils, in part, how many soil samples need to be taken.Weed seeds typically are not distributed randomly across a field. Weed seed bank is always highly aggregated in agriculture fields (Wiles and Schwezer, 1999; Chauvelet al. 1989).This basically means that many soil samples representative of seed bank for any particular species will have no seeds. For instance, Jones (1998), found thatat least half sample cores were devoid of the seeds when seed densities were less than 750 seeds $\mathrm{m}^{-2}$. It was found that the most common species had the highest value of seeds $\mathrm{m}^{-2}$ and the lowestCV.Forcellaet al. (1993) mentioned that species with very low densities $\left(<100\right.$ seeds $\left.\mathrm{m}^{-2}\right)$ would require so many soil cores to precisely determine seed bank is not practical.

Gholashan and Yasari (2012) found that in a comparison of sampling methods for estimating 
seed bank, the variance of error was stabilized and no more reduction of error was observed. They also found that 5 samples were almost the same as those from 30 samples and reliable to a large extent and at the same time very desirable soil surface at five scattered locations viz., centre, north, south, east and west, which were the studied basins namely; 5, 6, 12, 19 and 20 as shown in map (1).

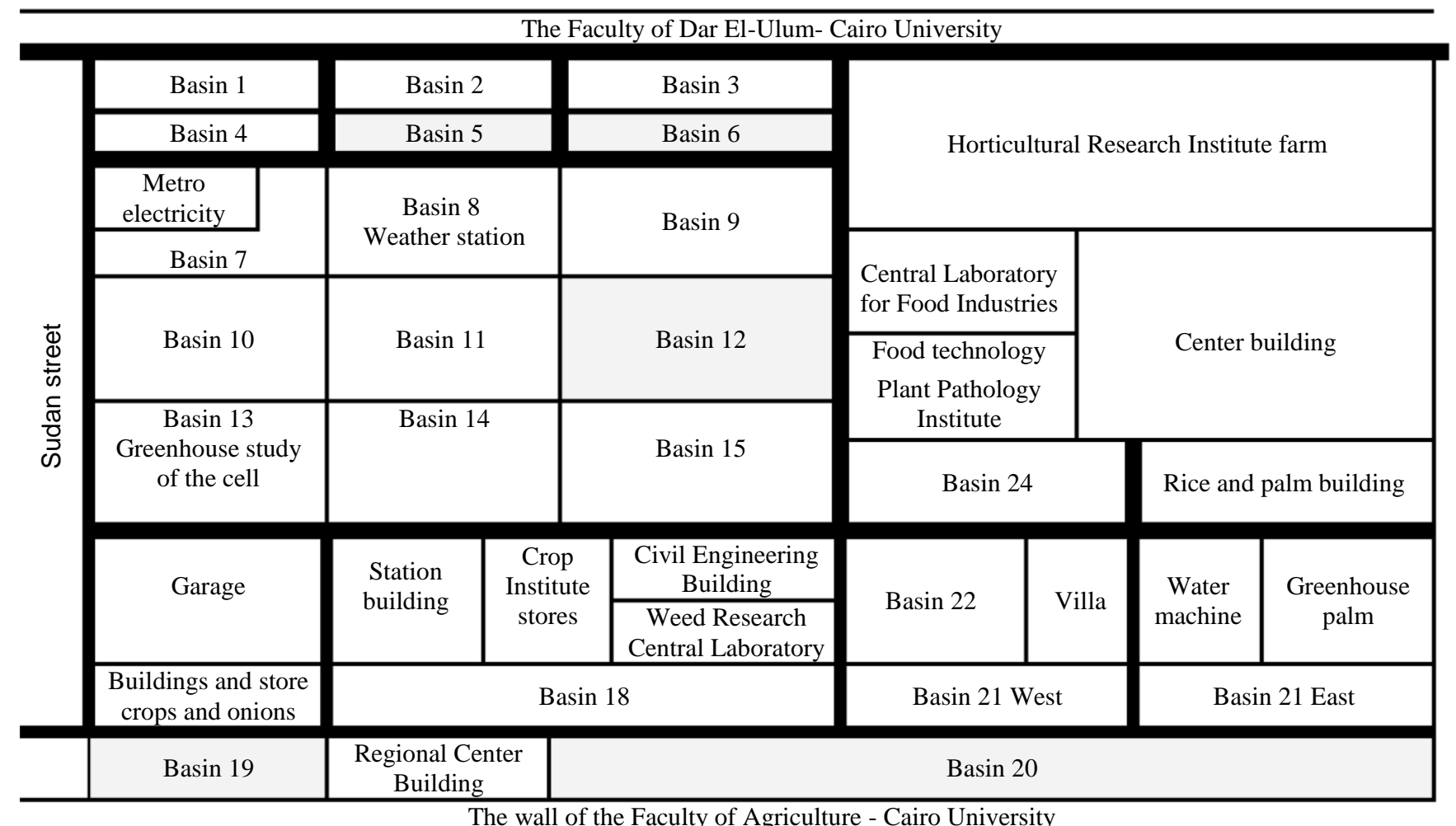

\section{Map (1): Map of the Agricultural Research Center, Giza, Egypt.}

as far as the required time and money are concerned. Distribution of the weed seed bank vertically in the soil profile depends on the type of tillage and is the main factor in determining the vertical distribution of weed seeds within the soil profile (Hossain and Begum 2015) and according to Forcella et al (2003). The present work depends on the use of germination method technique for enumerating seed in the soil seeds bank. Thus, the objective of the present study was to map the magnitude of winter seed bank horizontally in the studied basins and vertically in the soil profile in each basin and the suitable number of soil samples to determine a soil seed bank precisely in Giza research station.

\section{MATERIALS AND METHODS}

A study was designed to investigate the presence of the magnitude of winter weed seeds at different soil depths at different locations of the Agricultural Research Center farm, Giza Research Station during winter seasons of 2018 and 2019 at three depths $(5,10,15$ and $\mathrm{cm})$ from
Soil samples were taken in September. Number of the studied samples in each basin was 12 samples. Four soil samples were taken randomly for each depth $(0-5,5-10$ and 10-15 $\mathrm{cm}$ by auger $5 \mathrm{~cm}$ diameter and four sub soil samples as one $\mathrm{kg}$ from each basin. Soil samples were put into plastic pots in October at the Weed Research Central Laboratory, in clay loamy soil texture as shown in Table (1), and were watered regularly as needed. The recorded data were the number of germinated seedlings from weed seeds in each pot weekly for six weeks period. All the data for each basin were exposed to the proper statistical analysis according to the procedures outlined by Steel and Torrie, (1980), using Genstat $18^{\text {th }}$ edition to determine ANOVA table for one, two, three and four samples from each basin to determine L.S.D., (Last Significance Deference), CV (Coefficient of Variation) EE (Experiment Error) and SE (Sampling error) to compare the variance under each number of samples to determine the suitable samples number. 
Table (1): Mechanical and chemical soil analysis of the experimental site.

\begin{tabular}{|c|c|c|c|c|c|c|c|c|c|c|c|c|c|c|}
\hline \multicolumn{5}{|c|}{ Mechanical analysis \% } & \multicolumn{3}{|c|}{ Chemical analysis } & \multicolumn{3}{|c|}{ Anions Eqm/L } & \multicolumn{4}{|c|}{ Cations Eqm/L } \\
\hline $\begin{array}{c}\text { Basin } \\
\text { number }\end{array}$ & Sand & Silt & Clay & Texture & SP. & $\begin{array}{c}\text { PH } \\
(1: 2.5)\end{array}$ & $\begin{array}{c}\text { E.C } \\
\text { ds/m }\end{array}$ & $\mathrm{HCO}_{3}^{-}$ & Cl & $\mathrm{SO}_{4}=$ & $\mathrm{Ca}^{++}$ & $\mathbf{M g}^{++}$ & $\mathrm{Na}^{+}$ & $\mathbf{K}^{+}$ \\
\hline 5 & 24.9 & 38.1 & 37 & $\begin{array}{l}\text { Clay } \\
\text { loamy }\end{array}$ & 48 & 8 & 6.27 & 1.2 & 8.5 & 1.8 & 3.8 & 1.81 & 5.7 & 0.19 \\
\hline 6 & 22.6 & 39.8 & 37.6 & $\begin{array}{c}\text { Clay } \\
\text { loamy }\end{array}$ & 45 & 8.09 & 1.98 & 1.9 & 13.3 & 2.7 & 5.2 & 3.48 & 9 & 0.22 \\
\hline 12 & 23.4 & 39.4 & 37.2 & $\begin{array}{c}\text { Clay } \\
\text { loamy }\end{array}$ & 57 & 8.22 & 1.79 & 1.7 & 11.2 & 2.9 & 4.9 & 2.75 & 8 & 0.15 \\
\hline 19 & 21.3 & 39.9 & 38.8 & $\begin{array}{c}\text { Clay } \\
\text { loamy }\end{array}$ & 67 & 8.3 & 2.08 & 1.2 & 14.9 & 2.8 & 5.7 & 3.75 & 8.7 & 0.75 \\
\hline 20 & 24.2 & 38.5 & 37.3 & $\begin{array}{l}\text { Clay } \\
\text { loamy }\end{array}$ & 48 & 8.11 & 2.55 & 2.5 & 18.8 & 3.2 & 7.1 & 4.03 & 12.5 & 0.87 \\
\hline
\end{tabular}

Soil analysis had been done in Soil and Water Institute, Agricultural Research Center, Egypt.

\section{RESULTS AND DISCUSSION \\ 3.1. Weed species composition}

Eighteen different weed species were found in the studied basins, namely Ammi majus L., Annagallis arvensis L., Avena spp, Bidens bipinnata L., Capesella bursa pastoris L., Chenopodium album L., chenopodium ambrosioides L., Cichorium pamilum Jacq. V. Endivia, Convolvulus arvensis L., Coronopus didymus (L.) Sm., Cynodon dactylon (L.) Pers., Cyperus rotundus L., Malva parviflora L., Medicago polymorpha L. (M. hispida Gaerth), Melilotus indica L. All., Rumex dentatus L., Sonchus oleraceus L., and Urtica urens L.

3.2. Biodervsity in the soil seed bank in vertical and horizontal distribution

Table (2) and Fig. (1) show large variation in weed seed bank size in vertical soil profile or horizontal distribution in studied basins in both studied winter seasons. The number of germinated seeds $/ \mathrm{kg}$ of soil through $15 \mathrm{~cm}$ soil profile sections varied greatly from one basin to another. These differences may be attributed to the differences in crop sequences and tillage systems which followed in these basins. In all basins, most of the weed seeds were concentrated in $0-5 \mathrm{~cm}$ soil layer followed by 5 $10 \mathrm{~cm}$ soil layer and the lowest once were found in $10-15 \mathrm{~cm}$ soil layer. These results were statistically true and in agreement with those obtained by Prabhu et al. (2015) who mentioned that smaller size of seed bank at $15-30 \mathrm{~cm}$ than 0-15 cm soil depth. Khan et al. (2012), mentioned that the majority of the weed seed germinated from the soil samples were collected from the above $5 \mathrm{~cm}$ soil surface.

On the other hand, horizontal seed bank distribution between various studied basins showed that the total seed bank in $0-15 \mathrm{~cm}$ depth varied largely in the number of seeds/kg soil, which can be ranked from the highest seed bank to the lowest basin in the following order 375.5, $299.63,256.26,139.95$ and 65.56 seeds $/ \mathrm{kg}$ soil with basins No. 20, 12, 5, 6 and 19, respectively in the first season. The same trend was found in the second season with $456.88,295.94,188.69$, 89.34 and 87.69 seeds $/ \mathrm{kg}$ soil for basins No. 20, 12, 5, 19 and 6, respectively. Douglas et al. (2001) also found concentrated weed seed in the upper $10 \mathrm{~cm}$ of the soil profile due to different cultural practices. Our findings are in conformity with those of Mirsky et al. (2010) and Khan et al. (2012) who also reported that when the soil disturbance was deep, the maximum seed go deep into the soil and increased the soil seed bank.

\subsection{Determination of suitable number of germination cycle}

Results in Table (3) and Fig. (2) show that 56 weekly cycles for weed germination are needed to determine germinated winter weed seeds $\mathrm{kg}^{-1}$ soil through winter season, where most of weed seeds germinated in the $1^{\text {st }} \& 2^{\text {nd }}$ weeks and decreased gradually in the $5^{\text {th }} \& 6^{\text {th }}$ weeks. The germinated weed seeds in the $6^{\text {th }}$ week represent less than 5 percent from the total germinated weed seeds. These results were observed in both studied seasons. These results are in harmony with this obtained by Khan et al. (2012).

\subsection{Number of samples, experimental error and coefficient of variance $(\mathrm{CV} \%)$ and their relations to seed bank}

Table (4) and Fig. (3) show that the number of germinated seeds per kilogram of soil from soil surface until $15 \mathrm{~cm}$ depth, that $\mathrm{CV} \%$ values generally tend to decrease with increasing weed seed bank density in one side and the experimental error decreased with increasing the number of soil samples from 2-4 samples than 
M.F. El-enany, et al., ..........................................................................

Table (2): Vertical and horizontal distributions of germinated weed seeds in soil profile in studied basins in Giza research station during 2018 and 2019 winter seasons.

\begin{tabular}{|c|c|c|c|c|c|}
\hline \multirow{2}{*}{ Basin number } & \multirow{2}{*}{$\begin{array}{l}\text { Soil depths } \\
\quad \text { (cm) }\end{array}$} & \multicolumn{2}{|c|}{2018 winter season } & \multicolumn{2}{|c|}{2019 winter season } \\
\hline & & No. of seedling $\mathrm{kg}^{-1}$ & Seedling \% & No. of seedling $\mathrm{kg}^{-1}$ & Seedling \% \\
\hline \multirow[t]{5}{*}{5} & $0-5$ & 123.13 & 48.05 & 76.63 & 40.61 \\
\hline & $5-10$ & 87.44 & 34.12 & 67.38 & 35.71 \\
\hline & $10-15$ & 45.69 & 17.83 & 44.69 & 23.68 \\
\hline & L.S.D. 0.05 & \multicolumn{2}{|l|}{0.885} & \multicolumn{2}{|l|}{0.797} \\
\hline & Total & 256.26 & 100.00 & 188.69 & 100.00 \\
\hline \multirow[t]{5}{*}{6} & $0-5$ & 58.88 & 42.07 & 38.69 & 44.12 \\
\hline & $5-10$ & 52.19 & 37.29 & 29.94 & 34.14 \\
\hline & $10-15$ & 28.88 & 20.63 & 19.06 & 21.74 \\
\hline & L.S.D. 0.05 & \multicolumn{2}{|l|}{0.905} & \multicolumn{2}{|l|}{0.517} \\
\hline & Total & 139.95 & 100.00 & 87.69 & 100.00 \\
\hline \multirow[t]{5}{*}{12} & $0-5$ & 130.56 & 43.58 & 137.63 & 46.50 \\
\hline & $5-10$ & 100.25 & 33.46 & 94.81 & 32.04 \\
\hline & $10-15$ & 68.81 & 22.97 & 63.50 & 21.46 \\
\hline & L.S.D. 0.05 & \multicolumn{2}{|l|}{0.696} & \multicolumn{2}{|l|}{0.703} \\
\hline & Total & 299.63 & 100.00 & 295.94 & 100.00 \\
\hline \multirow[t]{5}{*}{19} & $0-5$ & 31.44 & 47.95 & 43.56 & 48.76 \\
\hline & $5-10$ & 24.94 & 38.04 & 33.83 & 37.87 \\
\hline & $10-15$ & 9.19 & 14.01 & 11.95 & 13.38 \\
\hline & L.S.D. 0.05 & \multicolumn{2}{|l|}{0.262} & \multicolumn{2}{|l|}{0.319} \\
\hline & Total & 65.56 & 100.00 & 89.34 & 100.00 \\
\hline \multirow[t]{5}{*}{20} & $0-5$ & 111.38 & 29.66 & 139.07 & 30.44 \\
\hline & $5-10$ & 123.44 & 32.87 & 155.31 & 33.99 \\
\hline & $10-15$ & 140.69 & 37.47 & 162.50 & 35.57 \\
\hline & L.S.D. 0.05 & \multicolumn{2}{|l|}{1.141} & \multicolumn{2}{|l|}{1.179} \\
\hline & Total & 375.50 & 100.00 & 456.88 & 100.00 \\
\hline
\end{tabular}

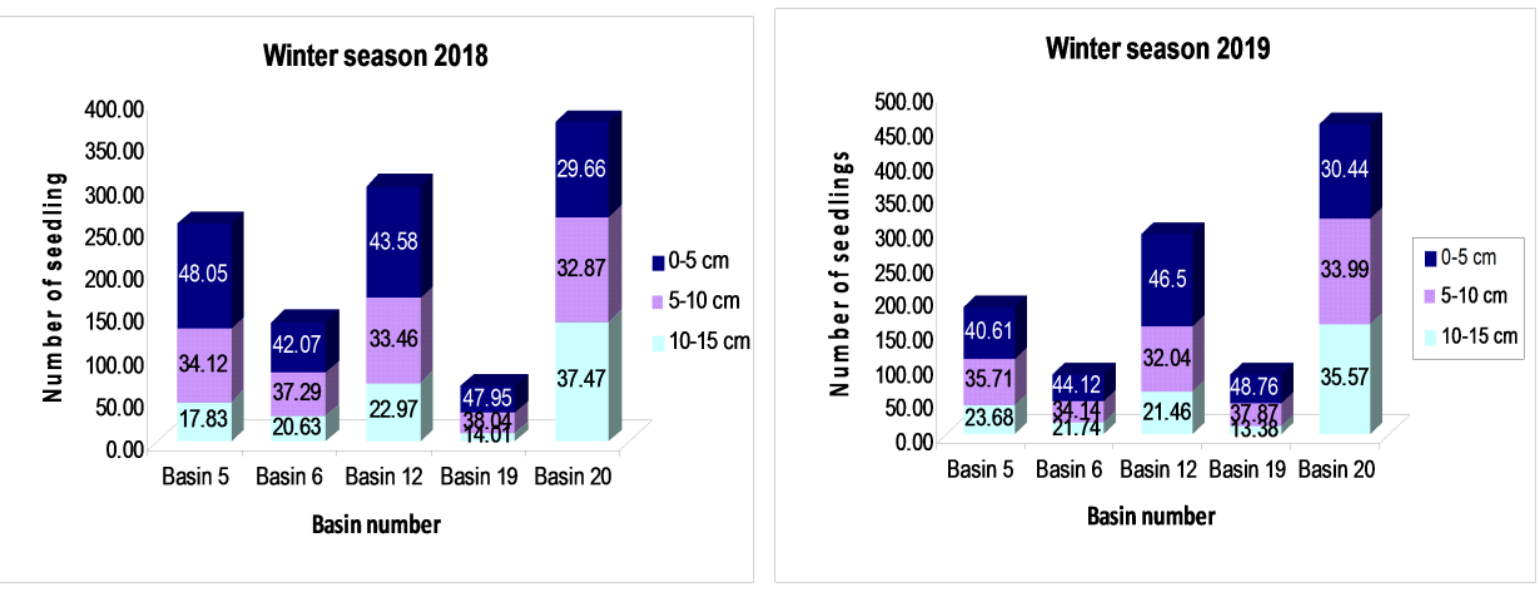

Fig. (1): Variation in weed seed bank size in vertical soil profile in one side and horizontal distribution in studied basins in both studied winter seasons 2018 \& 2019. 
Preliminary study on germinable winter weed seed bank at ..............................................

Table (3): Number of germinated weed seeds weekly during six weeks of irrigation in 2018 and 2019 winter seasons.

\begin{tabular}{|c|c|c|c|c|c|}
\hline \multirow{2}{*}{$\begin{array}{c}\text { Basin } \\
\text { number }\end{array}$} & \multirow{2}{*}{$\begin{array}{c}\text { Weeks after } \\
\text { irrigation }\end{array}$} & \multicolumn{2}{|c|}{ Winter 2018} & \multicolumn{2}{|c|}{ Winter 2019} \\
\hline & & No. of seedlings & Seedlings \% & No. of seedlings & Seedlings $\%$ \\
\hline \multirow{8}{*}{5} & First & 90.06 & 35.15 & 98.25 & 52.07 \\
\hline & Second & 71.13 & 27.76 & 48.75 & 25.84 \\
\hline & Third & 37.81 & 14.76 & 19.13 & 10.14 \\
\hline & Fourth & 36.19 & 14.12 & 14.31 & 7.59 \\
\hline & Fifth & 18.75 & 7.32 & 5.81 & 3.08 \\
\hline & Sixth & 2.31 & 0.90 & 2.44 & 1.29 \\
\hline & Total & 256.26 & 100.00 & 188.69 & 100.00 \\
\hline & L.S.D. 0.05 & \multicolumn{2}{|l|}{1.252} & \multicolumn{2}{|l|}{1.127} \\
\hline \multirow{8}{*}{6} & First & 89.44 & 63.91 & 24.75 & 28.23 \\
\hline & Second & 27.94 & 19.96 & 37.88 & 43.19 \\
\hline & Third & 9.13 & 6.52 & 12.25 & 13.97 \\
\hline & Fourth & 6.13 & 4.38 & 6.00 & 6.84 \\
\hline & Fifth & 5.94 & 4.25 & 3.88 & 4.42 \\
\hline & Sixth & 1.38 & 0.98 & 2.94 & 3.35 \\
\hline & Total & 139.95 & 100.00 & 87.69 & 100.00 \\
\hline & L.S.D. 0.05 & \multicolumn{2}{|l|}{1.279} & \multicolumn{2}{|l|}{0.732} \\
\hline \multirow{8}{*}{12} & First & 99.06 & 33.06 & 105.13 & 35.52 \\
\hline & Second & 71.13 & 23.74 & 71.75 & 24.24 \\
\hline & Third & 51.94 & 17.33 & 48.44 & 16.37 \\
\hline & Fourth & 37.81 & 12.62 & 33.00 & 11.15 \\
\hline & Fifth & 24.50 & 8.18 & 24.31 & 8.22 \\
\hline & Sixth & 15.19 & 5.07 & 13.31 & 4.50 \\
\hline & Total & 299.63 & 100.00 & 295.94 & 100.00 \\
\hline & L.S.D. 0.05 & \multicolumn{2}{|l|}{0.985} & \multicolumn{2}{|l|}{0.994} \\
\hline \multirow{8}{*}{19} & First & 23.06 & 35.18 & 37.76 & 42.27 \\
\hline & Second & 16.81 & 25.64 & 35.62 & 39.87 \\
\hline & Third & 12.69 & 19.35 & 6.13 & 6.86 \\
\hline & Fourth & 6.50 & 9.91 & 4.88 & 5.46 \\
\hline & Fifth & 4.38 & 6.67 & 3.63 & 4.06 \\
\hline & Sixth & 2.13 & 3.24 & 1.32 & 1.48 \\
\hline & Total & 65.56 & 100.00 & 89.34 & 100.00 \\
\hline & L.S.D. 0.05 & \multicolumn{2}{|l|}{0.371} & \multicolumn{2}{|l|}{0.452} \\
\hline \multirow{8}{*}{20} & First & 102.88 & 27.40 & 104.63 & 22.90 \\
\hline & Second & 92.25 & 24.57 & 125.38 & 27.44 \\
\hline & Third & 59.88 & 15.95 & 99.69 & 21.82 \\
\hline & Fourth & 53.94 & 14.36 & 65.81 & 14.40 \\
\hline & Fifth & 44.69 & 11.90 & 44.13 & 9.66 \\
\hline & Sixth & 21.88 & 5.83 & 17.25 & 3.78 \\
\hline & Total & 375.50 & 100.00 & 456.88 & 100.00 \\
\hline & L.S.D. 0.05 & \multicolumn{2}{|l|}{1.614} & \multicolumn{2}{|l|}{1.667} \\
\hline
\end{tabular}



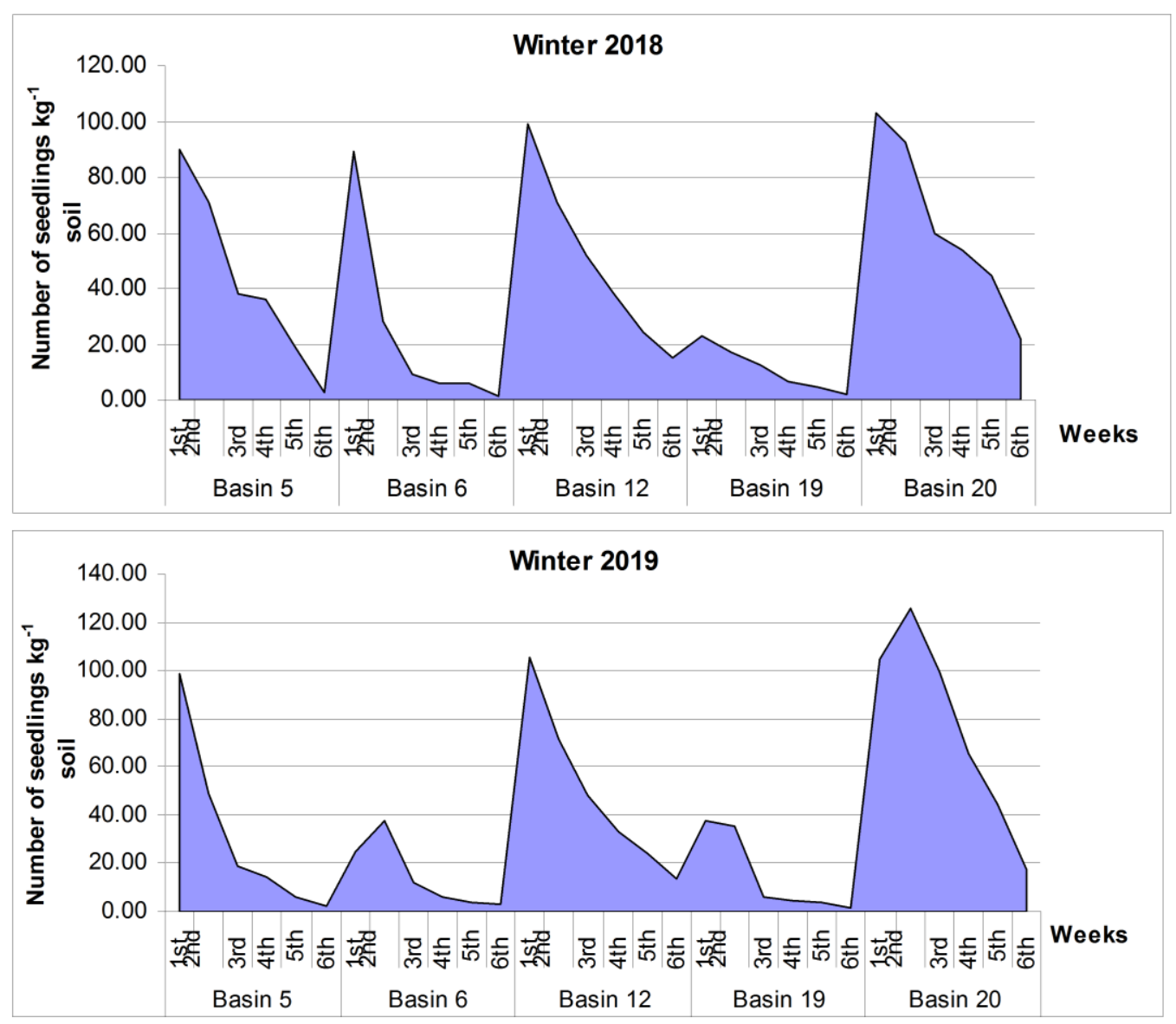

Fig. (2): Number of germinated seeds weekly in each kg soil during 2018 and 2019 winter seasons.
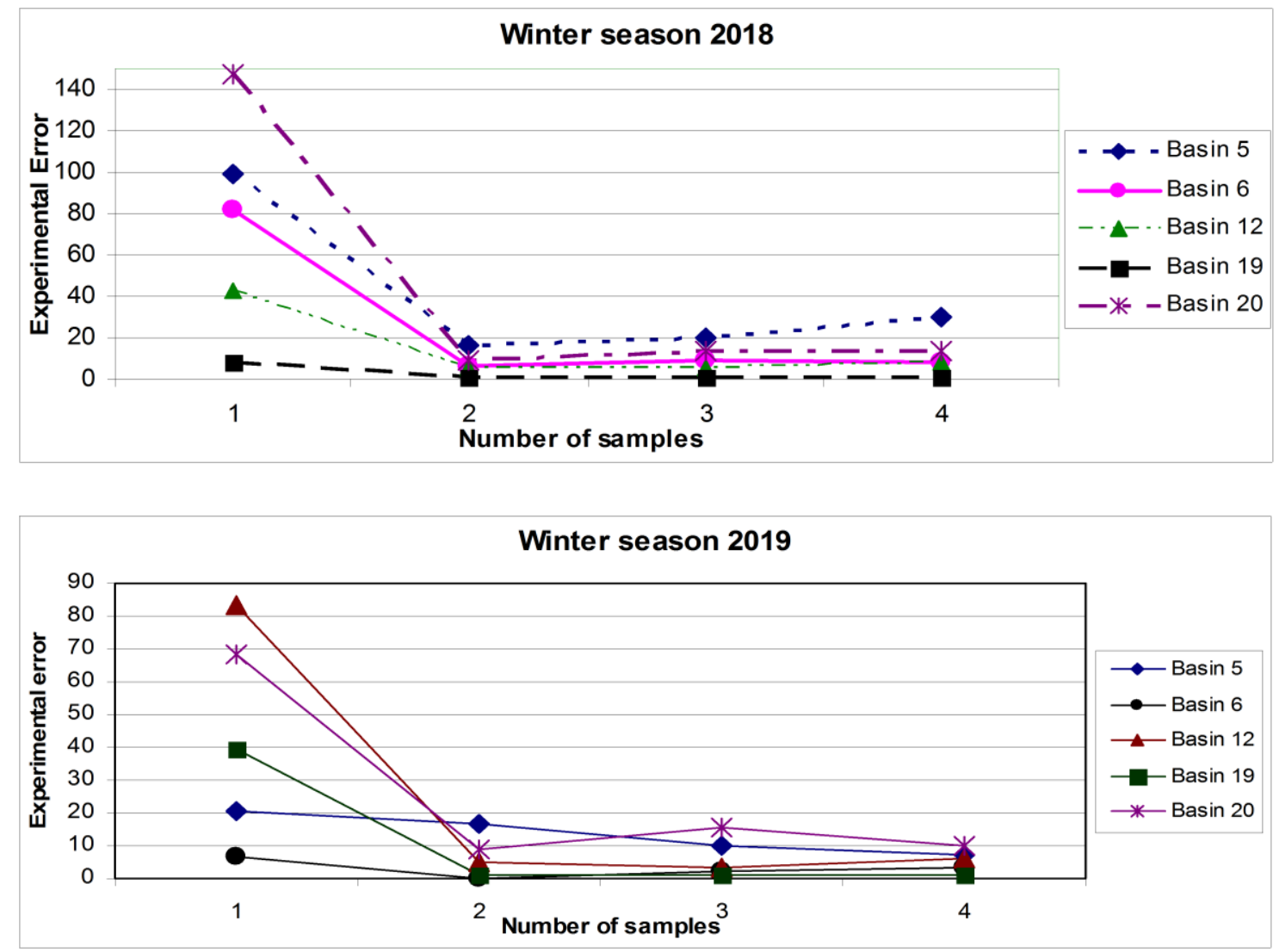

Fig. (3): The relationship between the number of the studied soil samples and experimental error during 2018 \& 2019 
Table (4): Horizontal distribution and number of soil samples of non dormant weed seed bank in the studied Giza station's basins during 2018 \& 2019 winter seasons.

\begin{tabular}{|c|c|c|c|c|c|c|c|c|c|}
\hline \multirow{3}{*}{$\begin{array}{c}\text { Basin } \\
\text { number }\end{array}$} & & \multicolumn{8}{|c|}{ Number of samples } \\
\hline & & \multicolumn{4}{|c|}{2018} & \multicolumn{4}{|c|}{2019} \\
\hline & & One & Two & Three & Four & One & Two & Three & Four \\
\hline \multirow{4}{*}{5} & $\begin{array}{l}\text { Total number of } \\
\text { seedlings } \mathrm{kg}^{-1}\end{array}$ & 269.5 & 262 & 259.584 & 256.255 & 186.5 & 190.875 & 190.002 & 188.69 \\
\hline & Experimental error & 98.64 & 15.96 & 19.63 & 29.90 & 20.43 & 16.80 & 9.80 & 7.30 \\
\hline & Sampling error & 11.168 & 7.514 & 9.796 & 9.678 & 17.507 & 9.715 & 9.468 & 7.85 \\
\hline & CV\% & 22.3 & 18.8 & 21.7 & 21.9 & 40.4 & 29.4 & 29.2 & 26.7 \\
\hline \multirow{4}{*}{6} & $\begin{array}{l}\text { Total number of } \\
\text { seedlings kg-1 }\end{array}$ & 151.25 & 146.75 & 141.75 & 139.95 & 92.75 & 90.88 & 89.08 & 87.69 \\
\hline & Experimental error & 81.70 & 6.70 & 4.90 & 8.30 & 6.70 & 1.80 & 2.50 & 3.20 \\
\hline & Sampling error & 10.43 & 10.71 & 8.70 & 10.11 & 2.01 & 3.42 & 2.87 & 3.31 \\
\hline & CV\% & 38.4 & 40.1 & 37.3 & 40.9 & 27.5 & 36.6 & 34.2 & 37.3 \\
\hline \multirow{4}{*}{12} & $\begin{array}{l}\text { Total number of } \\
\text { seedlings kg-1 }\end{array}$ & 301.5 & 305.5 & 302.67 & 299.63 & 302.25 & 300.25 & 299.5 & 295.94 \\
\hline & Experimental error & 42.90 & 5.10 & 5.44 & 8.22 & 83.32 & 5.20 & 3.60 & 5.92 \\
\hline & Sampling error & 6.41 & 7.11 & 5.48 & 5.99 & 5.015 & 4.11 & 4.63 & 6.11 \\
\hline & CV\% & 15.1 & 15.7 & 13.9 & 14.7 & 13.3 & 12.2 & 12.9 & 15.0 \\
\hline \multirow{4}{*}{19} & $\begin{array}{l}\text { Total number of } \\
\text { seedlings kg-1 }\end{array}$ & 64.5 & 65 & 65.83 & 65.56 & 90 & 91.38 & 90.83 & 89.34 \\
\hline & Experimental error & 7.8 & 0.8 & 0.8 & 0.8 & 39.49 & 1.16 & 0.86 & 1.09 \\
\hline & Sampling error & 1.02 & 0.99 & 0.97 & 0.85 & 1.74 & 2.04 & 1.43 & 1.26 \\
\hline & CV\% & 28.2 & 27.5 & 26.9 & 25.3 & 26.3 & 28.1 & 23.7 & 22.6 \\
\hline \multirow{4}{*}{20} & $\begin{array}{l}\text { Total number of } \\
\text { seedlings kg-1 }\end{array}$ & 376 & 374.63 & 374.92 & 375.5 & 464.75 & 463.63 & 457.83 & 456.88 \\
\hline & Experimental error & 147.6 & 8.8 & 13.7 & 13.4 & 68.30 & 9.02 & 15.44 & 10.23 \\
\hline & Sampling error & 10.84 & 8.29 & 14.07 & 16.10 & 9.71 & 10.76 & 15.42 & 17.17 \\
\hline & CV\% & 18.8 & 13.8 & 18.0 & 19.2 & 12.1 & 12.7 & 15.4 & 16.3 \\
\hline
\end{tabular}

one soil sample. In general four samples were more adequate than 2-3 samples, whereas one sample was not accurate in seed bank determination at all which had high experimental error. Some researchers as Gholashan and Yasari (2012) found that five samples were almost the same as 30 samples and it is highly desirable to save time and money to estimate seed bank.

\section{REFERENCES}

Chauvel B., Gasquez J. and Darmency H. (1989). Changes of weed seed bank parameters according to species, time and environment. Weed Res., 29: 213-219.

Douglas D.B., Kohler K.A. and Thompson R.I. (2001). Weed seed bank dynamics during a five-year crop rotation. Weed Technol. 15(1): 170-176.

Forcella F., Eradat-Oskoui K. and Wagner S.W. (1993). Application of weed seed bank ecology to low-input crop management. Ecol. Appl., 3:74-83.

Forcella F., Webster T. and Cardina J. (2003). Protocols for weed seed bank determination in agro-ecosystems. Weed management for developing countries 120 Addendum, FAO edition, Labrada, pp. 118.

Gholashan M. G. and Yasari E. (2012). Comparison of sampling methods for estimating seed bank and weed population densities during the growing season. J. Agric. Sci., 4, 9, 39-47.

Hossain M. M. and Begum M. (2015). Soil weed seed bank: Importance and management for sustainable crop production- A Review. J. Bangladesh Agril. Univ., 13(2): 221-228.

Jones N. (1998). Number of soil cores required to accurately estimate the seed bank on 
arable land. Aspects Appl. Biolo., 51: 1-8. Khan A. M., Hussain Z., Khan I., Khan R., Waqas M., Haroon M., Ali Z. and Khan I. A. (2012). Studies on weed seed bank of new developmental farm, KPK Agricultural University Peshawar, Pakistan., Pak. J. Weed Sci. Res., 18(2): 183-189.

Mirsky S.B., Gallandt E.R., Curran W.S. and Shumway D.L. (2010). Reducing the germinable weed seedbank with soil disturbance and cover crops. Weed Res., 50:341-352.
Prabhu G., Srinivasan R., Kantwa S. R., Palsaniya D. R. and Chaudhary M. (2015). Weed seed bank studies in the field of Fodder Cowpea [Vigna unguiculata (L.)]. Int'1. J. Appl. Pure Sci. Agric. (IJAPSA), 1,5 .

Steel R.G.D and Torrie J.H. (1980). Principles and Procedures of Statistics. McGraw Hill Book Co., Inc. New York. USA. pp. 481.

Wiles L. J. and Schweizer E. G. (1999). The cost of counting and identifying weed seeds and seedlings. Weed Sci., 47: 66-673.

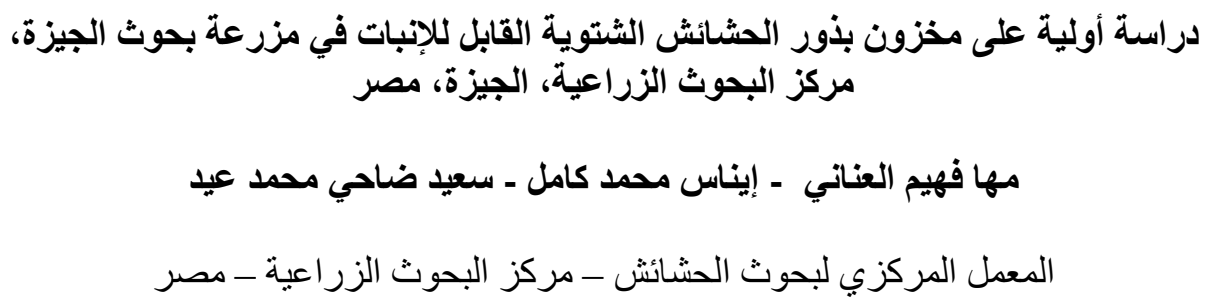

أصبحت در اسات مخزون البذور في التربة هي حجر الزاوية وأحد مكونات الإدارة المتكاملة للحشائش في النظم

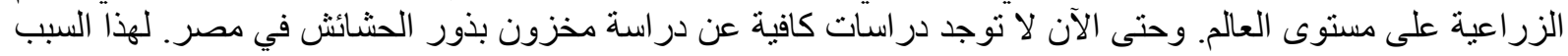

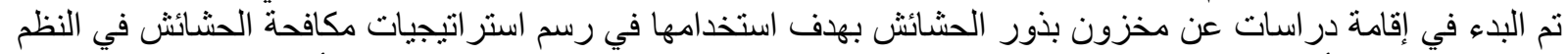
الزر اعية بمصر. أجريت هذه الدر اسة في الموسم الشتوي لعامي 2018، 2019 في عدد خمس أحواض اضد بمحطة البحوث

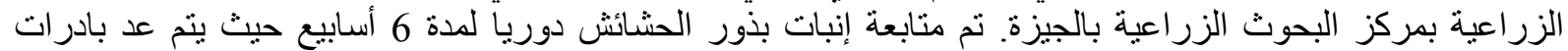

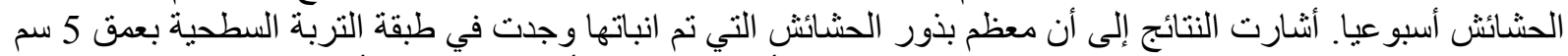

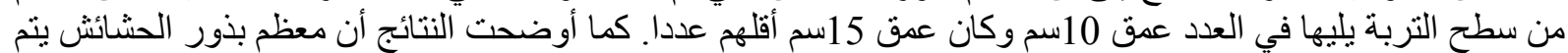

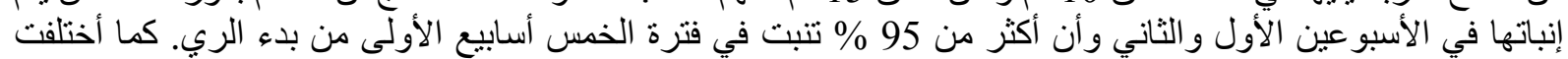

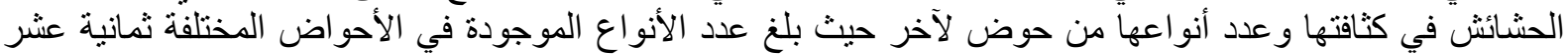

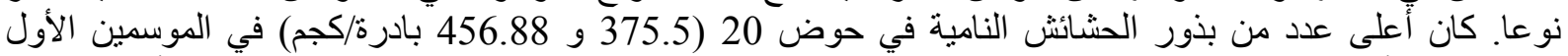

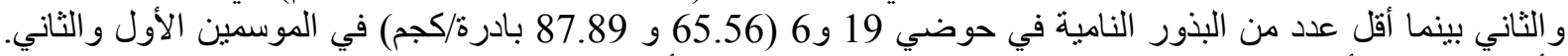

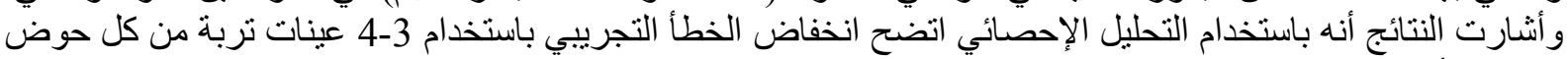

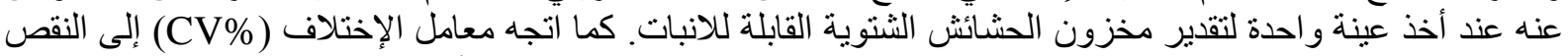

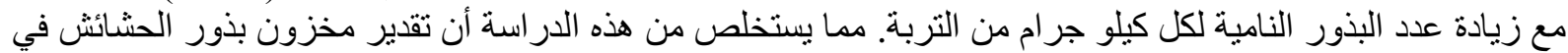

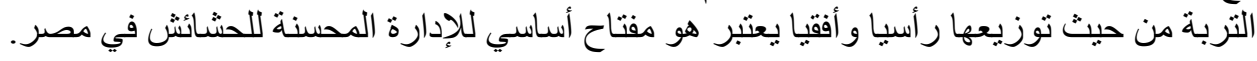

